\title{
PELATIHAN PENERAPAN PEMBIAYAAN SYARIAH DENGAN AKAD MUSYARAKAH MUTANAQISHAH (MMQ) Kerjasama dengan Koperasi Syariah Anazta Nusantara Sejahtera Desa Banyukapah, Kecamatan Kedungdung, Kabupaten Sampang
}

\author{
Oleh:

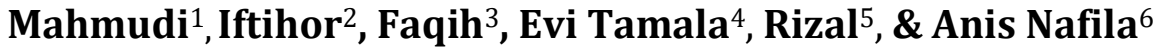 \\ Dosen IAI Nazhatut Thullab Sampang1,2,3 \\ Mahasiswa IAI Nazhatut Thullab Sampang 4,5,6 \\ E-mail: muchmode08@gmail.com¹,iftihor.kacong@gmail.com² \\ as.faqih08@gmail.com ${ }^{3}$
}

\begin{abstract}
Abstrak:
Tujuan dari kegiatan pengabdian ini adalah memberikan edukasi kepada masyarakat, khusunya tentang Lembaga Keuangan Syariah (LKS) dengan Akad Musyarakah Mutanaqishah yang sedang marak dijalankan oleh masyarakat desa Banyukapah, sebagaimana merupakan salah satu bentuk dalam pembiayaan Syariah yang dapat dimanfaatkan untuk Bisnis baik perorangan maupun sebuah lembaga, agar setiap transaksi untuk pembelian aset usaha (investasi) atau pengembangan usaha yang mereka jalankan sesuai dengan ketentuan-ketentuan akad syariah. Pelaksanakan kegiatan pelatihan penerapan akad Musyarakah Mutanaqishah dilaksanakan dengan menggunakan metode pelatihan dan pendampingan, dimana pelaksanaan kedua metode tesebut dilakukan dengan cara: Ceramah/Pemberian Informasi, Diskusi, Simulasi dan Pendampingan. Hasil kegiatan pelatihan antara lain: a). Masyarakat desa Banyukapah sudah mulai memahami dan mengetahui praktek akad Musyarakah Mutanaqishah yang sesuai ketentuan syariah, b). masyarakat desa Banyukapah sudah mulai memperbaiki praktek akad Musyarakah Mutanaqishah yang telah mereka jalankan.
\end{abstract}

Kata Kunci: Pelatihan, Lembaga Keuangan Syariah, Akad Musyarakah Mutanaqishah.

\section{PENDAHULUAN}

Lembaga keuangan syariah merupakan instrumen dalam menerapkan sistem ekonomi di bidang pengelolaan keuangan, baik menghimpun dana maupun menyalurkan dana. ${ }^{1}$ Dengan adanya Lembaga keuangan syariah atau lembaga

\footnotetext{
${ }^{1}$ Rizki Dian Mensari, Ahmad Dzikra. Islam Dan Lembaga Keuangan Syariah. AL-INTAJ Vol. 3, No. 1, Maret 2017.
} 
perbankan memberikan pengaruh pada perekonomian suatu Negara. Lembaga perbankan juga sangat dibutuhkan pemerintah dan masyarakat. Dengan diiringi pertumbuhan dan perkembangan perbankan terus meningkat, salah satu perkembangan perbankan adalah lahirnya Bank Syariah. ${ }^{2}$

Dalam istilah fiqh terdapat tiga istilah tentang pengertian percampuran, kemitraan, persekutuan, dan perkongsian yaitu al musyarakat, syirkah, dan syarikat. Oleh karena itu, literatur ilmu fiqh lebih banyak menggunakan istilah ini sedangkan peraturan perbankan syariah mempergunakan istilah musyarakah. Musyarakah Mutanaqishah merupakan bagian atau bisa juga kelanjutan dari musyarakah. Musyarakah merupakan istilah yang sering dipakai dalam konteks skim pembiayaan Syariah. Istilah ini berkonotasi lebih terbatas daripada istilah syirkah yang lebih umum digunakan dalam fikih Islam. Syirkah berarti sharing 'berbagi', dan dalam terminologi Fikih Islam dibagi dalam dua jenis yaitu Syirkah al-milk atau syirkah amlak atau syirkah kepemilikan, yaitu kepemilikan bersama dua pihak atau lebih dari suatu properti; dan Syirkah al-'aqad atau syirkah 'ukud atau syirkah akad, yang berarti kemitraan yang terjadi karena adanya kontrak bersama, atau usaha komersial bersama. ${ }^{3}$ Sehubungan dengan hal tersebut, dengan hadirnya pembiayaan musyārakah, diharapkan menjadi solusinya dari berbagai akad pembiayaan yang ada. Dalam hal ini, akad musyārakah akan lebih terstruktur realisasinya dengan menggunakan salah satu mode produk lembaga keuangan syariah (LKS) yaitu akad musyārakah mutanāqishah.

Akad tersebut juga sudah masuk dalam Kodifikasi Produk Perbankan Syariah Internasional Direktorat Perbankan Syariah Tahun 2008 dan memperoleh fatwa DSN MUI, Sebagaimana Akad Musyārakah mutanāqishah (diminishing partnership) adalah merupakan bentuk kerja sama antara dua pihak atau lebih untuk kepemilikan suatu barang atau aset. Dimana kerja sama ini akan mengurangi hak kepemilikan salah satu pihak, sementara pihak yang lain

\footnotetext{
2 Putri Kamilatur Rohmi. Implementasi Akad Musyarakah Mutanaqishah Pada Pembiayaan Kepemilikan Rumah di Bank Muamalat Lumajang. Iqtishoduna Vol. 5 No. 1 April 2015.

${ }^{3}$ Ainul Imronah. Musyarakah Mutanaqishah. Fakultas Ekoomi dan Bisnis Islam. AL-INTAJ Vol. 4, No. 1, Maret 2018.
} 
bertambah hak kepemilikannya. Perpindahan kepemilikan ini melalui mekanisme pembayaran atas hak kepemilikan yang lain. Bentuk kerja sama ini berakhir dengan pengalihan hak salah satu pihak kepada pihak lain. ${ }^{4}$

Musyarakah Mutanaqishah (MMQ) adalah salah satu produk pengembangan dari produk berbasis akad Musyarakah. Musyarakah Mutanaqishah dapat diaplikasikan sebagai suatu produk pembiayaan perbankan syariah berdasarkan prinsip syirkah 'inan, dimana porsi modal (hishshah) salah satu syarik (mitra) yaitu Bank berkurang disebabkan oleh pembelian atau pengalihan komersial secara bertahap (naqlul hishshah bil 'iwadh mutanaqishah) kepada syarik (mitra) yang lain yaitu Nasabah. Musyarakah mutanaqishah (diminishing partnership) adalah bentuk kerjasama antara dua pihak atau lebih untuk kepemilikan suatu barang atau asset. ${ }^{5}$

Dasar hukum tentang Musyārakah mutanāqishah ini berdasarkan AlQur'an, hadist dan Ijma'. Sebagaimana yang difirmankan Allah SWT dalam AlQur'an Surat Shad [38], ayat 24, serta Al-Qur'an Surat al-Qashash [28], ayat 26. Sebagaimana merupakan sandaran hukum Islam pada pembiayaan musyarakah mutanaqishah, pada saat ini, dimana pada akad musyarakah (kemitraan) dan ijarah (sewa). Karena di dalam akad musyarakah mutanaqishah terdapat unsur syirkah dan unsur ijarah. Al-Qur'an Surat Shad [38], ayat 24, serta Al-Qur'an Surat al-Qashash [28], ayat 26. Begitu juga Para ahli hukum Islam secara sepakat mengakui keabsahan musyarakah mutanaqishah ditinjau dari segi kebutuhan dari manfaat pada suatu segi dan karena sesuatu dengan ajaran dan tujuan syariah dan segi lainnya. ${ }^{6}$

Akad musyarakah merupakan bentuk umum dari usaha bagi hasil. Musyarakah biasa dikenal dengan istilah syirkah yang berarti kongsi, serikat, atau kerjasama. Akad ini dilandasi keinginan semua pihak untuk bekerjasama

\footnotetext{
${ }^{4}$ Dadin Solihin. Abin Suarsa. Bentuk Pembiayaan Musyarakah Mutanaqishah Di Lembaga Keuangan Syariah. Jurnal Ilmiah MEA (Manajemen, Ekonomi, \& Akuntansi)| Volume 3 No. 1 Januari - April 2019.

5 Putri Dona Balgis. Akad Musyarakah Mutanaqisa: Inovasi Baru Produk Pembiayaan Bank Syariah. Volume VII, No. 1: 14-21. Jurnal Ekonomi Syariah Indonesia, Juni 2017.

${ }^{6}$ Nadratuzzaman Hosen. Musyarakah Mutanaqishah. Al-Iqtishad: Vol. I, No. 2, Juli 2009.
} 
meningkatkan nilai aset yang dimiliki bersamasama. Bentuk kerjasama yang dilakukan dapat diterapkan pada usaha yang baru maupun yang sudah berjalan. ${ }^{7}$

Dalam pembiayaan musyarakah mutanaqishah, status kepemilikan barang masih menjadi milik bersama antara pihak bank syariah dan nasabah. Hal ini merupakan konsekuensi dari pembiayaan musyarakah mutanaqishah, dimana kedua belah pihak ikut menyertakan dananya untuk membeli barang. Pada saat transfer kepemilikan barang, pihak nasabah dapat menguasai ke pemilikan barang sepenuhnya setelah dilakukan pembayaran bagian bank syariah oleh nasabah beserta besaran uang sewa yang disepakati bersama. ${ }^{8}$

Sistem Akad Musyarakah Mutanaqishah yang dijalankan masyarakat desa Banyukapah adalah Akad antara dua pihak atau lebih yang berserikat atau berkongsi terhadap suatu barang yang salah satu pihak kemudian membeli bagian pihak lainnya secara bertahap. Namun Pada pelaksanaannya, sering terjadi permasalahan yang muncul karena sistem bagi hasil yang tidak jelas, seperti halnya jika terjadi peristiwa force major pada saat perjanjian bagi hasil. Pada kondisi ini selalu ada pihak yang dirugikan, baik dari pemilik modal maupun nasabah. Berangkat dari permasalahan di atas, Koprasi Syariah Anazta Nusantara Sejahtera menggandeng kami dosen prodi Ekonomi Syariah IAI Nazhatut Thullab untuk melakukan pengabdian masyarakat dengan memberikan edukasi dan pemahaman kepada masyarakat terkait Akad Musyarakah Mutanaqishah yang sesuai dengan ketentuan syariah, sehingga dalam prosesnya tidak ada pihak yang merasa dirugikan.

\section{METODE PENGABDIAN}

Untuk memecahkan masalah yang telah diidentifikasi dan dirumuskan diatas, maka pelaksanaan kegiatan pengabdian ini dilakukan dengan menggunakan

\footnotetext{
7 Rahmawaty. Implication of Musyarakah Mutanaqisah Contract of Syariah Banking (Study of Opportunities and Risks at Bank Mu'amalat, Manado Branch). Tasharruf: Journal Economic and Business Of Islam. Vol. 3 No. 2. Desember 2018.

${ }^{8}$ Nadratuzzaman Hosen. Musyarakah Mutanaqishah. Al-Iqtishad: Vol. I, No. 2, Juli 2009.
} 
metode pelatihan dan pendampingan, dimana kedua metode tersebut dilakukan dengan cara :

1. Ceramah / Pemberian Informasi dan simulasi; Kegiatan ini dimulai dengan pemberian informasi sekaligus memberikan simulasi kepada masyarakat berkaitan seputar Akad Musyarakah Mutanaqishah dengan menggunakan metode cemarah. Kegiatan ini dilakukan dengan harapan masyarakat memiliki pemahaman yang baik terkait Akad Musyarakah Mutanaqishah dan bisa mengaplikasikannya dalam praktek transaksi keseharian mereka.

2. Diskusi / Tanya jawab; metode ini digunakan agar masyarakat bisa bertanya tentang hal-hal yang belum mereka fahami dan menjadi polemik diantara mereka.

3. Pendampingan; dalam kegiatan ini kami mendampingi masyarakat secara langsung di lapangan, untuk melakukan dan memperbaiki Akad Musyarakah Mutanaqishah yang baik dan benar sesuai dengan ketentuan Akad Musyarakah Mutanaqishah.

\section{HASIL DAN PEMBAHASAN}

Langkah-langkah dan tahapan dalam kegiatan pengabdian yang dikemas dengan pelatihan ini melalui beberapa tahapan, yaitu;

1. Persiapan; Tim pengabdian yang terdiri dari dosen dan mahasiswa IAI Nazhatut Thullab serta tim dari Koperasi Syariah Anazta memberikan konfirmasi dan permohonan izin kepada kepala desa setempat, dan ketua yayasan Nurudz Dzolam mengenai rencana program atau kegiatan yang akan dilakukan selama pengabdian atau pelatihan.

2. Sosialisasi; Tim pengabdian masyarakat menjelaskan tentang berbagai kegiatan yang akan diikuti dan juga berkaitan dengan mekanisme pelaksanaan kegiatan, mulai dari proses pendaftaran, penentuan peserta yang akan dilibatkan dalam pelaksanaan kegiatan pengabdian atau pelatihan dan membuat kesepakatan dengan masing-masing peserta untuk terlibat secara aktif dalam mengikuti dan menjalankan program pelatihan yang sudah direncanakan. 
3. Pelatihan Dasar; peserta yang telah terdaftar, dalam hal ini adalah masyarakat yang akan di assessment dulu tentang motivasi dan kemampuan dasarnya tentang Akad Musyarakah Mutanaqishah, peserta akan diundang mengikuti pelatihan dasar sesuai dengan agenda kegiatan yang telah disepakati, kegiatan pelatihan ini tidak dilakukan dalam satu kali pelatihan tetapi bertahap.

4. Pelatihan lanjutan; Tim pengabdian memberikan pelatihan lanjutan dengan fokus pada pendalaman tentang Akad Musyarakah Mutanaqishah khususnya tentang akad dua pihak atau lebih yang berserikat atau berkongsi terhadap suatu barang yang salah satu pihak kemudian membeli bagian pihak lainnya secara bertahap yang sesuai dengan ketentuan syariah.

5. Pendampingan; Tim pengabdian mengadakan pendampingan kepada masyarakat dalam melakukan Akad Musyarakah Mutanaqishah yang sesuai dengan ketentuan syariah sebagaimana yang mereka ketahui dalam proses pelatihan.

6. Evaluasi; Tim pengabdian masyarakat bersama-sama mengadakan evaluasi terhadap kegiatan pelatihan dan pendampingan kegiatan, evaluasi juga dilakukan secara bersama-sama dengan masyarakat peserta untuk melihat kemajuan dan penerapan Akad Musyarakah Mutanaqishah dalam kegiatan transaksi yang dijalankan oleh masyarakat dan perumusan pengembangan kegiatan dan perluasan kelompok di masa depan.

\section{Tahap Pelaksanaan Kegiatan}

Kemudian, dalam kegiatan pelatihan penerapan Akad Musyarakah Mutanaqishah di desa Banyukapah telah dilaksanakan dengan baik sesuai rencana yang telah disiapkan. Pelaksanaan Kegiatan dimulai dengan melalui tahapan sebagai berikut:

\section{Persiapan}

Kegiatan ini memerlukan waktu yang lebih lama dalam persiapan pelaksanaannya untuk menjamin tingkat kesuksesan dalam seluruh program kegiatan tersebut. Adapun persiapan yang dilakukan meliputi : 
a. Menentukan lokasi (lembaga yang menjadi mitra pengabdian masyarakat) dan menentukan peserta yang menjadi sasaran pelaksanaan kegiatan pelatihan penerapan Akad Musyarakah Mutanaqishah.

b. Mengurus perijinan kegiatan kepada kepala desa setempat.

c. Melakukan sosialisasi terhadap mitra kegiatan untuk memastikan keberlangsungan kegiatan ini dengan mengungkapkan time schedule dan hal-hal yang menjadi konsekuensi kegiatan tersebut,

d. Mempersiapkan materi pelatihan dan pembuatan modul Akad Musyarakah Mutanaqishah yang akan diberikan kepada seluruh peserta dan mitra kegiatan.

\section{Pelaksanaan}

Dalam tahap pelaksanaan kegiatan pengabdian masyarakat ini sesuai dengan rencana pelaksanaan dan kesepakatan dengan mitra kegiatan. Tahapan kegiatan tersebut antara lain:

a. Pendistribusian modul Akad Musyarakah Mutanaqishah; Kegiatan ini bertujuan untuk memberikan bekal kepada peserta agar dapat melakukan kegiatan transaksi Akad Musyarakah Mutanaqishah dengan lebih baik. Modul ini berisikan tentang petunjuk praktis dalam melakukan Akad Musyarakah Mutanaqishah. Modul ini diberikan kepada seluruh peserta dan pengurus lembaga sebagai mitra kegiatan pengabdian ini. Diharapkan modul ini dapat dijadikan referensi bagi masyarakat dalam pelaksanaan Akad Musyarakah Mutanaqishah.

b. Pelatihan dasar; Kegiatan berikutnya adalah melakukan pelatihan dasar akad mudharabah untuk peserta kegiatan. Tujuan dari kegiatan ini adalah: Memperkenalkan akad Akad Musyarakah Mutanaqishah yang sesuai dengan ketentuan syariah kepada masyarakat.

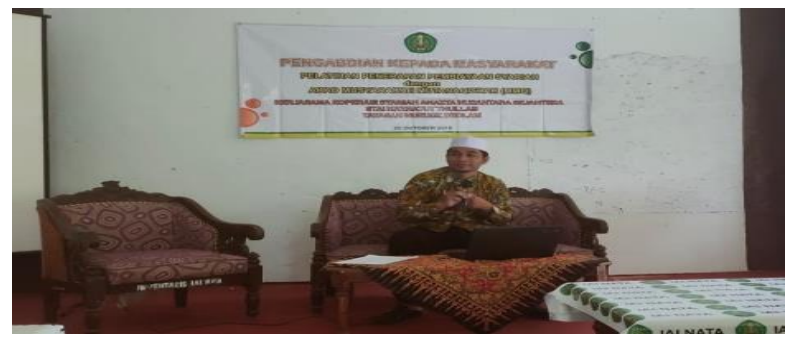




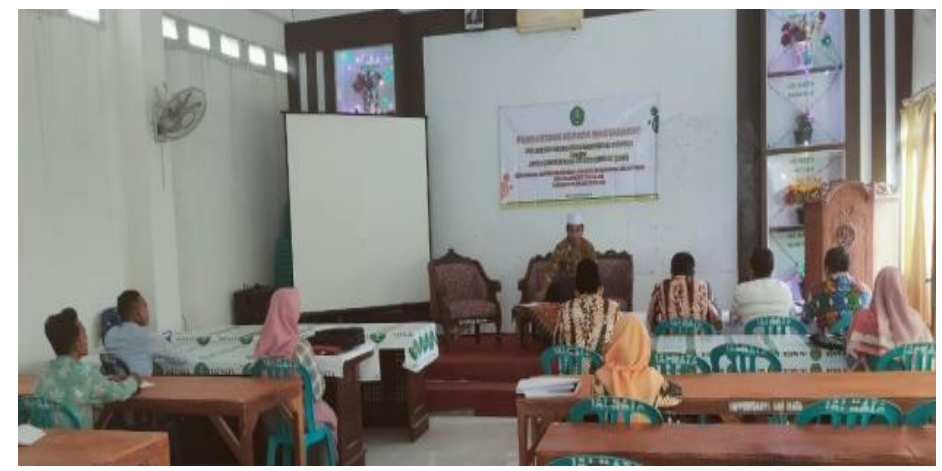

c. Pelatihan lanjutan, Sesuai dengan tujuan dilakukannya kegiatan pengabdian ini dan hasil evaluasi dari pelatihan dasar, maka dibutuhkan adanya pelatihan lanjutan. Kegiatan ini bertujuan untuk; Meningkatkan pemahaman dan pengetahuan masyarakat tentang akad Akad Musyarakah Mutanaqishah sehingga bisa diterapkan di lapangan dengan baik benar.

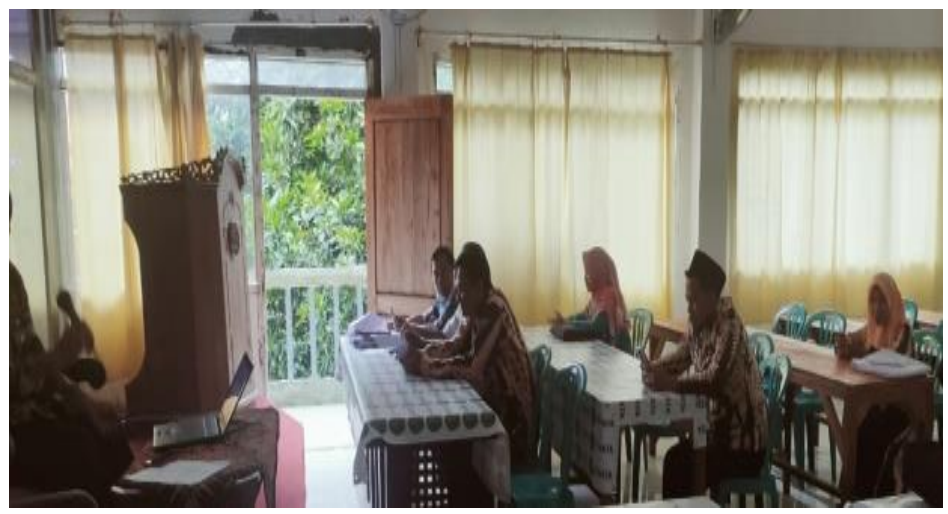

d. Pendampingan; Program pendampingan merupakan kegiatan yang disusun sebagai sebuah paket kegiatan untuk memastikan bahwa peserta melakukan kegiatan Akad Musyarakah Mutanaqishah dan memiliki kemampuan dasar yang dibutuhkan saat melakukan melakukan akad. Disamping itu kegiatan ini juga untuk menjembatani informasi terbaru berkaitan dengan permasalahan yang dihadapi oleh masyarakat, sehingga tim pengabdian masyarakat dapat menyusun langkah-langkah baru dan membantu penyelesaian masalah yang dihadapi oleh peserta dan mitra. Selain itu kegiatan pendampingan juga digunakan untuk melakukan sharing terhadap permasalahan yang dihadapi masyarakat. Program pendampingan dilakukan selama 3 kali sesuai dengan 
kesepakatan dengan mitra yaitu Koprasi Syariah Anazta untuk memberikan pendampingan terhadap kegiatan transaksi di lokasi masing-masing. Kegiatan ini juga dimaksudkan untuk menjalin komunikasi yang lebih baik antara peserta masyarakat, tim pengabdian (mentor) dan pihak kampus, agar kerjasama yang dilakukan ini dapat berkesinambungan untuk kepentingan masyarakat yang lebih luas.

\section{Faktor Pendukung dan Penghambat}

Berdasarkan evaluasi pelaksanaan dan hasil kegiatan dapat diidentifikasi faktor pendukung dan penghambat dalam melaksanakan program pengabdian pada masyarakat ini. Secara garis besar faktor pendukung dan penghambat tersebut adalah sebagai berikut:

\section{Faktor pendukung;}

Ada beberapa faktor yang mendukung suksesnya kegiatan pengabdian masyarakat yang dikemas dalam bentuk pelatihan ini, antara lain :

a. Tersedianya tenaga ahli yang memadai dalam pengembangan modul pelatihan Akad Musyarakah Mutanaqishah yaitu dosen prodi Ekonomi Syariah IAI Nazhatut Thullab dan Koprasi Syariah Anazta,

b. Antusiasme masyarakat yang cukup tinggi untuk mengikuti kegiatan pelatihan penerapan Akad Musyarakah Mutanaqishah.

c. Dukungan kepala desa Banyukapah, dan lembaga mitra kegiatan pengabdian masyarakat yang menyambut baik pelaksanaan kegiatan pelatihan dan membantu tim pengabdi mengorganisasikan waktu dan tempat pelaksanaan kegiatan, dan

d. Ketersediaan dana pendukung dari fakultas guna penyelenggaraan kegiatan pengabdian pada masyarakat ini.

\section{Faktor Penghambat}

Mungkin istilah "tidak ada yang sempurna di dunia ini", juga berlaku pada kegiatan yang dilakukan oleh tim pengabdian, dalam menjalankan program dan kegiatan yang sudah direncanakan tentunya juga tidak terlepas dari beberapa masalah dan hambatan, walaupun secara umum kegiatan ini bisa 
dikatakan berjalan dengan baik dan berhasil. Diantara faktor penghambat yang berhasil diidentifikasi adalah sebagai berikut :

a. Masyarakat peserta pelatihan masih banyak yang belum memiliki pengetahuan awal dan dasar tentang Akad Musyarakah Mutanaqishah yang sesuai dengan ketentuan syariah,

b. Keterbatasan waktu untuk pelaksanaan pelatihan sehingga beberapa materi tidak dapat disampaikan secara detil, hal ini dikarenakan kesibukan masyarakat peserta yang bisa dikatakan beraneka ragam.

\section{Hasil Kegiatan Pengabdian}

Berangkat dari Tujuan kegiatan pengabdian ini yaitu memberikan edukasi kepada masyarakat, khusunya tentang Akad Musyarakah Mutanaqishah yang sedang marak dijalankan oleh masyarakat, agar setiap transaksi Akad Musyarakah Mutanaqishah yang mereka jalankan sesuai dengan ketentuan-ketentuan akad syariah, maka setelah dilakukan kegiatan pengabdian dengan cara pelatihan dan pendampingan, tim pengabdian menemukan bahwa: Masyarakat desa Banyukapah banyak yang belum memahami Akad Musyarakah Mutanaqishah yang benar, khususnya terkait dua pihak atau lebih yang berserikat atau berkongsi terhadap suatu barang yang salah satu pihak kemudian membeli bagian pihak lainnya secara bertahap, namun setelah kegiatan ini masyarakat sudah mulai memahami dan memperbaiki Akad Musyarakah Mutanaqishah yang telah mereka jalankan.

\section{KESIMPULAN}

Berdasarkan implementasi kegiatan pengabdian masyarakat dan evaluasi dengan mitra dapat disimpulkan bahwa kegiatan ini berhasil dijalankan dengan baik, hal ini dibuktikan dengan bertambahnya pengetahuan masyarakat tentang praktek Akad Musyarakah Mutanaqishah yang benar, dan yang paling penting adalah masyarakat sudah mulai membenahi praktek akad dua pihak atau lebih yang berserikat atau berkongsi terhadap suatu barang yang salah satu pihak kemudian membeli bagian pihak lainnya secara bertahap yang telah lama mereka jalankan. 
Berdasarkan evaluasi yang telah dilakukan dapat diajukan beberapa saran yakni: a) Waktu pelaksanaan kegiatan pengabdian perlu ditambah agar tujuan kegiatan dapat tercapai sepenuhnya, tetapi dengan konsekuensi penambahan biaya pelaksanaan. Oleh karena itu biaya pengabdian kepada masyarakat sebaiknya tidak sama antara beberapa tim pengusul proposal, mengingat khalayak sasaran yang berbeda pula. b) Adanya kegiatan lanjutan yang berupa pelatihan sejenis selalu diselenggarakan secara periodik sehingga dapat menciptakan masyarakat yang menjunjung tinggi akad-akad yang sesuai dengan syariah.

\section{DAFTAR PUSTAKA}

Ainul Imronah. Musyarakah Mutanaqishah. Fakultas Ekoomi dan Bisnis Islam. ALINTAJ Vol. 4, No. 1, Maret 2018.

Dadin Solihin. Abin Suarsa. Bentuk Pembiayaan Musyarakah Mutanaqishah Di Lembaga Keuangan Syariah. Jurnal Ilmiah MEA (Manajemen, Ekonomi, \& Akuntansi)| Volume 3 No. 1 Januari - April 2019.

Putri Kamilatur Rohmi. Implementasi Akad Musyarakah Mutanaqishah Pada Pembiayaan Kepemilikan Rumah di Bank Muamalat Lumajang. Iqtishoduna Vol. 5 No. 1 April 2015.

Putri Dona Balgis. Akad Musyarakah Mutanaqisa: Inovasi Baru Produk Pembiayaan Bank Syariah. Volume VII, No. 1: 14-21. Jurnal Ekonomi Syariah Indonesia, Juni 2017.

Nadratuzzaman Hosen. Musyarakah Mutanaqishah. Al-Iqtishad: Vol. I, No. 2, Juli 2009.

Rizki Dian Mensari, Ahmad Dzikra. Islam Dan Lembaga Keuangan Syariah. ALINTAJ Vol. 3, No. 1, Maret 2017. 